\title{
SZKOLNICTWO WYŻSZE NA LITWIE W OKRESIE 1989-2014 - OD INTERWENCJONIZMU DO LIBERALIZMU
}

\begin{abstract}
Streszczenie
W artykule dokonano analizy reformy szkolnictwa wyższego na Litwie, przeprowadzonej w okresie 19892014. Pierwszym etapem było utworzenie dwufilarowego modelu szkolnictwa wyższego - uniwersytety i kolegia. Kolejny etap stanowiło zbudowanie prywatnego sektora szkolnictwa wyższego w obu filarach. Końcowym etapem reformy było wprowadzenie liberalnego narzędzia „koszyka studenta”, co zmieniło finansowanie edukacji wyższej. Decyzją sądu konstytucyjnego Litwy w grudniu 2011 roku takie rozwiązania finansowania szkolnictwa wyższego ograniczono tylko do uczelni państwowych. Liberalny model finansowania szkolnictwa wyższego zostawiono tylko dla 10\% kwoty finansów przyznanych na szkolnictwo wyższe.
\end{abstract}

Słowa kluczowe: polityka szkolnictwa wyższego, model edukacji wyższej, finansowanie szkolnictwa wyższego, regulowanie (interwencjonizm) państwowe, liberalny model „koszyk studenta”

\section{HIGHER EDUCATION IN LITHUANIA DURING 1989-2014: FROM INTERVEN- TIONISM TO LIBERALISM}

\section{Summary}

The paper analyses the reform of higher education in Lithuania conducted in the period 1989-2014. The first step was to create a binary model of higher education, consisting of universities and colleges. The next step was to build a private sector of both types of higher education institutions. The final stage of the reform was the introduction of liberal instruments, i.e. student vouchers, which changed the financing of higher education. According to the decision of the Constitutional Court of Lithuania in December 2011, this type of funding is limited only to state universities. The liberal model of financing higher education in 2012 concerned only $10 \%$ of the amount allocated for this purpose.

Key words: higher education policy, model of higher education, higher education funding, state regulation (interventionism), liberal model of student vouchers

\section{Wstęp}

Celem badawczym artykułu jest przedstawienie wyników analizy reformy modelu szkolnictwa wyższego na Litwie w okresie 1989-2014. Do osiagnięcia postawionego celu wykorzystano metodę analizy porównawczej.

\footnotetext{
${ }^{1}$ Dr hab. Jarosław Wołkonowski, prof. UwB - Wydział Ekonomiczno-Informatyczny w Wilnie, Uniwersytet w Białymstoku; e-mail: wolkonowski@uwb.edu.pl.
} 
W 1990 roku, po uzyskaniu niepodległości przez państwo litewskie, został przejęty postsowiecki system szkolnictwa wyższego - państwo z budżetu finansowało wyższe uczelnie. Otrzymany w spadku po transformacji systemowo-gospodarczej postsowiecki model szkolnictwa wyższego działał na zasadzie interwencjonizmu państwowego, był kosztochłonny oraz nieefektywny. Kilkanaście uniwersytetów oraz kilkadziesiąt szkół zawodowych miało stworzyć nowoczesny system szkolnictwa wyższego, opierający się na tradycyjnej autonomii [Antonowicz, 2005, s. 37-38] wyższej szkoły oraz na liberalnym, ale również sprawiedliwym, społecznym modelu edukacji wyższej. Wymagało to przejścia od zastanego modelu bezpłatnych studiów do studiów częściowo odpłatnych. Wprowadzono także liberalne ${ }^{2}$ rozwiązania, dążąc do częściowej komercjalizacji systemu szkolnictwa wyższego, gdyż współczesne wyższe uczelnie powinny posiadać umiejętność adaptacji do nowych warunków społecznych i ekonomicznych [Antonowicz, 2005, s. 37-38].

Władze Litwy, reformując swój model szkolnictwa wyższego, korzystały z europejskich wzorców. Współczesny model szkolnictwa wyższego różnych krajów jest określany według tzw. trójkąta wpływów, w którego wierzchołkach znajdują się wpływy państwa, oligarchii akademickiej i rynku (model zaproponowany przez B. Clarka), [Thieme, 2009, s. 47]. Litwa otrzymała system szkolnictwa wyższego z wyraźną dominacją wpływów państwa. W swych działaniach mogła podążać w kierunku modelu z wyraźną dominacją oligarchii akademickiej, jednak grupa akademicka w tym okresie była za słaba, by przeforsować takie rozwiązanie. Trzeci model, w którym wpływ rynku na szkolnictwo wyższe ma decydujące znaczenie, został przyjęty na Litwie jako najbardziej odpowiedni [Thieme, 2009, s. 48-49].

Według klasyfikacji Brauna i Merriena modelu szkolnictwa wyższego, opierającego się również na trzech kryteriach: 1. siły bezpośredniego nakazowo-materialnego oddziaływania państwa na uczelnię (duża-D lub mała-M); 2. sposobu prawno-proceduralnego oddziaływania państwa na uczelnie tzw. gorset (ścisły-S lub luźny-L); 3. politycznie obowiązującego systemu wartości wyznaczającego cele wyższego wykształcenia (kulturowy-K lub usługowy-U), [Thieme, 2009, s. 52-53] - wybór władz politycznych Litwy oscylował między rozwiązaniem $\mathrm{M}+\mathrm{S}+\mathrm{K}$ a $\mathrm{M}+\mathrm{L}+\mathrm{U}$, co oznaczało utworzenie modelu pośredniego między biurokratyczno-oligarchicznym a modelem rynkowym [Thieme, 2009, s. 54-55]. Należy równocześnie zauważyć, że współczesne uczelnie wyższe w Europie są uczelniami trzeciej generacji, na których nie kształci się wyłącznie specjalistów i naukowców, ale także przedsiębiorców, oraz szeroko wykorzystuje się know-bow [Zymonik, 2010, s. 244-245]. Reformując model szkolnictwa wyższego, władze Litwy musiały uwzględnić nie tylko nowoczesne trendy, lecz jednocześnie wziąć pod uwagę przestrzenną i regionalną strukturę edukacji wyższej [Marszałek, 2010, s. 209].

\section{Stan szkolnictwa wyższego na Litwie w okresie 1989-2014}

Zastany po czasach sowieckich system szkolnictwa wyższego składał się z 13 państwowych uniwersytetów i 66 państwowych szkół zawodowych, które na początku lat

\footnotetext{
${ }^{2}$ Liberalizm odegrał dużą rolę w ideowych i organizacyjnych podstawach autonomii uniwersytetów [Antonowicz, 2005, s. 42-43].
} 
dziewięćdziesiątych przekształcono w tzw. szkoły pomaturalne (litewskie ankšstesnioji mokykla - dosłowne tłumaczenie 'szkoła podwyższona'). Szkolnictwo wyższe na początku lat dziewięćdziesiątych było całkowicie utrzymywane $z$ budżetu państwa i studia były bezpłatne. Uniwersytety ${ }^{3}$ prowadzily jednolite cztero- lub pięcioletnie studia uniwersyteckie, po ich ukończeniu absolwentom wydawano dyplomy wykształcenia wyższego. Władze niepodległej Litwy poddały zastany system szkolnictwa wyższego ostrej krytyce, zarzucając mu niska jakość kształcenia, niedostosowanie studiów do potrzeb rynku oraz wysokie koszty kształcenia. W reformowanych szkołach zawodowych, które w okresie sowieckim dawały wykształcenie średnie i zawodowe, po 1990 roku (szkoły pomaturalne) mogły rozpocząć naukę tylko osoby mające średnie wykształcenie. Szkoły te zostały przekształcone w kolegia. Prowadzily one tak zwane studia nieuniwersyteckie, które były skierowane na zdobycie praktycznych umiejętności.

TABELA 1.

Liczba szkół wyższych i studentów w latach 1989-2014

\begin{tabular}{|c|c|c|c|c|c|c|}
\hline $\begin{array}{l}\text { Rok } \\
\text { akade- } \\
\text { micki }\end{array}$ & $\begin{array}{l}\text { Liczba uni- } \\
\text { wersytetów }\end{array}$ & $\begin{array}{c}\text { Liczba } \\
\text { studentów } \\
\text { na uniwer- } \\
\text { sytetach }\end{array}$ & $\begin{array}{c}\text { Liczba szkół } \\
\text { pomatural- } \\
\text { nych }\end{array}$ & $\begin{array}{c}\text { Liczba studentów } \\
\text { w szkołach pomatu- } \\
\text { ralnych }\end{array}$ & $\begin{array}{l}\text { Liczba } \\
\text { kole- } \\
\text { giów }\end{array}$ & $\begin{array}{l}\text { Liczba stu- } \\
\text { dentów } \\
\text { w kolegiach }\end{array}$ \\
\hline 1989-1990 & 13 & 69500 & 66 & 51700 & - & - \\
\hline 1990-1991 & 13 & 67300 & 64 & 46405 & - & - \\
\hline 1991-1992 & 14 & 60500 & 65 & 36976 & - & - \\
\hline 1992-1993 & 14 & 55100 & 64 & 29911 & - & - \\
\hline 1993-1994 & 14 & 52800 & 60 & 24444 & - & - \\
\hline 1994-1995 & 15 & 51500 & 65 & 24034 & - & - \\
\hline 1995-1996 & 15 & 53968 & 67 & 24214 & - & - \\
\hline 1996-1997 & 15 & 58766 & 68 & 26492 & - & - \\
\hline 1997-1998 & 15 & 67068 & 70 & 30329 & - & - \\
\hline 1998-1999 & 15 & 74532 & 70 & 33881 & - & - \\
\hline 1999-2000 & 16 & 84345 & 69 & 38397 & - & - \\
\hline 2000-2001 & 19 & 95593 & 57 & 37378 & 7 & 3547 \\
\hline 2001-2002 & 19 & 106913 & 42 & 31964 & 16 & 10377 \\
\hline 2002-2003 & 19 & 119548 & 27 & 22367 & 24 & 26236 \\
\hline 2003-2004 & 21 & 130245 & 15 & 12262 & 27 & 40472 \\
\hline 2004-2005 & 21 & 138516 & 11 & 4842 & 27 & 52185 \\
\hline 2005-2006 & 21 & 141771 & 5 & 832 & 28 & 55949 \\
\hline 2006-2007 & 22 & 143204 & 1 & 16 & 28 & 56297 \\
\hline $2007-2008$ & 22 & 144336 & - & - & 28 & 60096 \\
\hline 2008-2009 & 22 & 149017 & - & - & 27 & 61383 \\
\hline 2009-2010 & 23 & 144301 & - & - & 23 & 56704 \\
\hline $2010-2011$ & 22 & 133564 & - & - & 23 & 53297 \\
\hline 2011-2012 & 23 & 125046 & - & - & 24 & 49777 \\
\hline 2012-2013 & 23 & 113780 & - & - & 24 & 45685 \\
\hline 2013-2014 & 23 & 104923 & - & - & 24 & 43550 \\
\hline
\end{tabular}

Źródło: [Statistical Yearbook of Lithuania 1989, 1990, s. 93; Statistical Yearbook of Lithuania 19941995, 1995, s. 421; Statistical Yearbook of Lithuania 1995-1996, 1996, s. 486; Statistical Yearbook of Lithuania 1996, 1996, s. 486; Departament Statystyki Litwy, dokument elektroniczny, tryb dostępu: [http://stat.gov.lt, data wejścia: 25.05.2014].

\footnotetext{
${ }^{3}$ Niektóre z uniwersytetów początkowo miały status instytutu, jak na przykład Wileński Instytut Pedagogiczny, który w 1992 roku uzyskał status Wileńskiego Uniwersytetu Pedagogicznego [Dokument elektroniczny, tryb dostępu: http://www.leu.lt/lt/apie_universiteta/istorija.html, data wejścia: 25.05.2014].
} 
Po dokonaniu pierwszych reform, na skutek trudnej sytuacji gospodarczej nastapił spadek liczby studentów na uczelniach wyższych na Litwie - zarówno na uniwersytetach, jak i w reformowanych szkołach pomaturalnych.

Pierwsze zmiany dotyczyły reform mających na celu zmianę statusu szkół wyższych w kierunku przyznania im większej samodzielności oraz politycznej zgody na wprowadzenie częściowej odpłatności za studia, co oznaczało komercjalizację.

\section{Model finansowania szkolnictwa wyższego w niepodległej Litwie}

W połowie lat dziewięćdziesiątych na uniwersytetach wprowadzono odpłatność za studia dla studentów, którzy nie dostali się na studia finansowane przez państwo i którzy byli gotowi uiścić pełną opłatę za kształcenie. Liczba takich studentów wzrastała od połowy lat dziewięćdziesiątych. Na studiach uniwersyteckich wdrożono dwustopniowy system szkolnictwa wyższego - studia I stopnia (licencjackie) i studia II stopnia (magisterskie).

TABELA 2.

Przyjęci na studia uniwersyteckie I stopnia (licencjackie) i II stopnia (magisterskie)

\begin{tabular}{|c|c|c|c|c|c|c|}
\hline Rok & $\begin{array}{l}\text { Liczba miejsc } \\
\text { na 1. roku } \\
\text { studiów } \\
\text { I stopnia } \\
\text { finansowa- } \\
\text { nych przez } \\
\text { państwo }\end{array}$ & $\begin{array}{c}\text { Liczba miejsc } \\
\text { na } 1 . \text { roku } \\
\text { studiów } \\
\text { płatnych } \\
\text { I stopnia }\end{array}$ & $\begin{array}{c}\text { Ogólna } \\
\text { liczba miejsc } \\
\text { płatnych } \\
\text { i finansowa- } \\
\text { nych przez } \\
\text { państwo na } \\
\text { 1. roku stu- } \\
\text { diów } \\
\text { I stopnia }\end{array}$ & $\begin{array}{c}\text { Liczba } \\
\text { miejsc na } \\
\text { 1. roku stu- } \\
\text { diów II stop- } \\
\text { nia finanso- } \\
\text { wanych przez } \\
\text { państwo }\end{array}$ & $\begin{array}{c}\text { Liczba miejsc } \\
\text { na } 1 \text {. roku } \\
\text { studiów płat- } \\
\text { nych } \\
\text { II stopnia }\end{array}$ & $\begin{array}{c}\text { Ogólna } \\
\text { liczba miejsc } \\
\text { płatnych } \\
\text { i finansowa- } \\
\text { nych przez } \\
\text { państwo na } \\
\text { 1. roku stu- } \\
\text { diów } \\
\text { II stopnia }\end{array}$ \\
\hline 2000 & 13506 & 11294 & 24800 & 6425 & 2756 & 9181 \\
\hline 2001 & 13637 & 14831 & 28468 & 5717 & 3930 & 9647 \\
\hline 2002 & 18388 & 11674 & 30062 & 4835 & 4873 & 9708 \\
\hline 2003 & 18205 & 13406 & 31611 & 4960 & 6097 & 11057 \\
\hline 2004 & 17639 & 13071 & 30710 & 5051 & 5841 & 10892 \\
\hline 2005 & 18025 & 13009 & 31034 & 4545 & 6739 & 11284 \\
\hline 2006 & 17323 & 13865 & 31188 & 5930 & 6014 & 11944 \\
\hline 2007 & 16894 & 15414 & 32308 & 5866 & 7486 & 13352 \\
\hline 2008 & 15508 & 18819 & 34327 & 5796 & 8030 & 13826 \\
\hline 2009 & 11483 & 17721 & 29204 & 4537 & 5237 & 9774 \\
\hline 2010 & 9524 & 12822 & 22346 & 4725 & 4703 & 9428 \\
\hline 2011 & 9386 & 13065 & 22451 & 5204 & 4355 & 9559 \\
\hline 2012 & 8753 & 13240 & 21993 & 4761 & 4422 & 9183 \\
\hline 2013 & 7992 & 12776 & 20745 & 4496 & 4148 & 8625 \\
\hline
\end{tabular}

Źródło: [Departament Statystyki Litwy, dokument elektroniczny, tryb dostępu: stat.gov.lt, data wejścia: 25.05.2014].

Szkoły pomaturalne od 2000 roku zaczęto przekształcać w kolegia, które według prawa Republiki Litewskiej uzyskały już status szkół wyższych nieuniwersyteckich. 
Po ich ukończeniu wydawano dyplom wyższego wykształcenia nieuniwersyteckiego i dyplom zawodowy4. Stały się one drugim filarem szkolnictwa wyższego, obok istniejącego szkolnictwa uniwersyteckiego. Kolegia również, obok studiów finansowanych przez budżet państwa, zaczęły prowadzić studia odpłatne dla kandydatów, którzy nie dostali się na studia finansowane przez państwo. Mimo że wysokość opłat za studia wzrastała, liczba studiujących odpłatnie także rosła. Jeżeli w roku akademickim 1995-1996 na uniwersyteckich studiach odpłatnych było tylko 7,6\% studentów [Želvys, 2013, s. 11], (I stopnia, zaś studia II stopnia były całkowicie finansowane przez państwo), to już w roku 2000-2001 w kolegiach Litwy na odpłatne studia na 1. rok przyjęto 42,3\% studentów, na uniwersytety natomiast - 45,5\% na studia I stopnia (licencjackie) i 30\% na studia II stopnia (magisterskie).

\section{Przyjęci na 1. rok studiów w kolegiach}

\begin{tabular}{|c|r|r|r|}
\hline Rok & $\begin{array}{c}\text { Liczba miejsc na 1. roku } \\
\text { studiów finansowanych } \\
\text { przez państwo }\end{array}$ & $\begin{array}{c}\text { Liczba miejsc na 1. } \\
\text { roku studiów płat- } \\
\text { nych }\end{array}$ & $\begin{array}{c}\text { Ogólna liczba miejsc } \\
\text { płatnych i finansowanych } \\
\text { przez państwo na stu- } \\
\text { diach na 1. roku }\end{array}$ \\
\hline 2000 & 1970 & 1443 & 3413 \\
2001 & 3891 & 2956 & 6847 \\
2002 & 8557 & 7240 & 15797 \\
2003 & 10100 & 10469 & 20569 \\
2004 & 10063 & 13798 & 23861 \\
2005 & 10737 & 10850 & 21587 \\
2006 & 10038 & 11100 & 21138 \\
2007 & 9993 & 13756 & 23749 \\
2008 & 9395 & 13564 & 22959 \\
2009 & 9287 & 7706 & 16993 \\
2010 & 8438 & 7520 & 15958 \\
2011 & 8672 & 7702 & 16374 \\
2012 & 7921 & 7502 & 15423 \\
2013 & 7455 & 6790 & 14235 \\
\hline
\end{tabular}

Źródło: [Departament Statystyki Litwy, dokument elektroniczny, tryb dostępu: stat.gov.lt, data wejścia: 25.05.2014].

Jednak komercjalizacja szkolnictwa wyższego wywoływała społeczne protesty, stąd w 2000 roku wprowadzono tzw. częściową odpłatność za studia dla połowy studentów przyjętych na studia finansowane przez państwo, która miała słabsze wyniki w nauce (początkowo $1000 \mathrm{Lt}$ za rok akademicki, następnie $1040 \mathrm{Lt}$ ). Rozwiązanie to miało na celu złagodzenie nierówności społecznych [Želvys, 2013, s. 9].

Kolejne zmiany w szkolnictwie wyżsym nastapily w 2000 roku, kiedy stworzono możliwości powołania niepaństwowych uniwersyteckich szkół wyższych oraz niepaństwowych kolegiów. Studia w prywatnych wyższych uczelniach były finansowane przez studentów i prywatne fundusze.

W 2007 roku Trybunał Konstytucyjny uznał, że szkoły wyższe (państwowe i niepaństwowe) mogą przyjąć na studia nieograniczoną liczbę kandydatów realizujących peł-

\footnotetext{
${ }^{4}$ Podaje to Ministerstwo Nauki i Oświaty Republiki Litewskiej na swej stronie [Dokument elektroniczny, tryb dostępu: http://www.smm.lt/web/lt/uzsienyje_igytu_kvalifikaciju_pripazinimas_LT/LT_ igtu_kvalifikacijos_pripazinimas/trumpa_info_apie_specialuji_vid_aukst_issilavinima, data wejścia: 25.05.2014].
} 
ną odpłatność za studia ${ }^{5}$. Wdrożono w ten sposób kolejne elementy wolnego rynku w szkolnictwie wyższym. Zasadnicza różnica między państwową szkołą wyższą a niepaństwowa polegała na tym, że ta pierwsza otrzymywała finansowanie z budżetu państwa na określone przez władze limity studentów i mogła dodatkowo jeszcze wprowadzić odpłatne studia. Jedynym źródłem finansowania działalności szkoły niepaństwowej były środki pochodzące z czesnego studenta.

TABELA 4.

\section{Szkoły wyższe państwowe i niepaństwowe na Litwie}

\begin{tabular}{|c|c|c|c|c|c|c|c|c|c|c|}
\hline $\begin{array}{l}\text { Rok aka- } \\
\text { demicki }\end{array}$ & $\begin{array}{l}\text { Liczba } \\
\text { uniwer- } \\
\text { sytetów } \\
\text { ogółem }\end{array}$ & $\begin{array}{c}\text { Liczba } \\
\text { uniwer- } \\
\text { sytetów } \\
\text { pań- } \\
\text { stwo- } \\
\text { wych }\end{array}$ & $\begin{array}{c}\text { Liczba } \\
\text { studen- } \\
\text { tów na } \\
\text { uniwer- } \\
\text { sytetach } \\
\text { państw- } \\
\text { owych }\end{array}$ & $\begin{array}{c}\text { Liczba } \\
\text { uniwer- } \\
\text { sytetów } \\
\text { niepań- } \\
\text { stwo- } \\
\text { wych }\end{array}$ & $\begin{array}{c}\text { Liczba } \\
\text { studen- } \\
\text { tów na } \\
\text { uniwer- } \\
\text { sytetach } \\
\text { niepań- } \\
\text { stwo- } \\
\text { wych }\end{array}$ & $\begin{array}{c}\text { Licz- } \\
\text { ba } \\
\text { kole- } \\
\text { giów } \\
\text { ogó- } \\
\text { łem }\end{array}$ & $\begin{array}{c}\text { Liczba } \\
\text { kole- } \\
\text { giów } \\
\text { pań- } \\
\text { stwo- } \\
\text { wych }\end{array}$ & \begin{tabular}{|} 
Liczba \\
studen- \\
tów \\
w kole- \\
giach \\
pań- \\
stwo- \\
wych
\end{tabular} & \begin{tabular}{|c|} 
Liczba \\
kolegiów \\
niepań- \\
stwo- \\
wych
\end{tabular} & $\begin{array}{l}\text { Liczba } \\
\text { studen- } \\
\text { tów } \\
\text { w kole- } \\
\text { giach } \\
\text { niepań- } \\
\text { stwo- } \\
\text { wych }\end{array}$ \\
\hline 1995-1996 & 15 & 15 & 53968 & - & - & - & - & - & - & - \\
\hline 1996-1997 & 15 & 15 & 58776 & - & - & - & - & - & - & - \\
\hline 1997-1998 & 15 & 15 & 67068 & - & - & - & - & - & - & - \\
\hline 1998-1999 & 15 & 15 & 74532 & - & - & - & - & - & - & - \\
\hline 1999-2000 & 16 & 15 & 84282 & 1 & 63 & - & - & - & - & - \\
\hline $2000-2001$ & 19 & 15 & 94871 & 4 & 722 & 7 & 4 & 2972 & 3 & 575 \\
\hline 2001-2002 & 19 & 15 & 105966 & 4 & 947 & 16 & 7 & 8463 & 9 & 1914 \\
\hline $2002-2003$ & 19 & 15 & 118289 & 4 & 1259 & 24 & 15 & 20955 & 9 & 5281 \\
\hline 2003-2004 & 21 & 15 & 126646 & 6 & 3599 & 27 & 16 & 32153 & 11 & 8319 \\
\hline 2004-2005 & 21 & 15 & 134203 & 6 & 4313 & 27 & 16 & 42119 & 11 & 10066 \\
\hline 2005-2006 & 21 & 15 & 136779 & 6 & 4992 & 28 & 16 & 44503 & 12 & 11446 \\
\hline 2006-2007 & 22 & 15 & 137514 & 7 & 5690 & 28 & 16 & 43484 & 12 & 12813 \\
\hline $2007-2008$ & 22 & 15 & 137205 & 7 & 7131 & 28 & 16 & 43651 & 12 & 16445 \\
\hline 2008-2009 & 22 & 15 & 140960 & 7 & 8057 & 27 & 15 & 43912 & 12 & 17471 \\
\hline $2009-2010$ & 23 & 15 & 136274 & 8 & 8027 & 23 & 13 & 41045 & 10 & 15659 \\
\hline $2010-2011$ & 22 & 14 & 125914 & 8 & 7650 & 23 & 13 & 39426 & 10 & 13871 \\
\hline 2011-2012 & 23 & 14 & 117797 & 9 & 7249 & 24 & 13 & 38119 & 11 & 11658 \\
\hline 2012-2013 & 23 & 14 & 106989 & 9 & 6791 & 24 & 13 & 36047 & 11 & 9638 \\
\hline 2013-2014 & 23 & 14 & 98943 & 9 & 6253 & 24 & 13 & 34662 & 11 & 8906 \\
\hline
\end{tabular}

Źródło: [Departament Statystyki Litwy, dokument elektroniczny, tryb dostępu: stat.gov.lt, data wejścia: 25.05.2014].

Z tabeli 4. wynika, że w pierwszej dekadzie XXI wieku na Litwie powstał sektor niepaństwowego szkolnictwa wyższego zarówno uniwersytecki, jak i drugiego filaru - kolegia. Należy jednak odnotować, że liczba studentów na uniwersytetach niepaństwowych stanowiła zaledwie 5,4\% ogólnej liczby studentów odbywających studia uniwersyteckie. Inaczej sytuacja wyglądała w kolegiach niepaństwowych, w których pod koniec pierwszej dekady XXI stulecia studiowało $28,5 \%$ ogólnej liczby studentów tego filaru szkolnictwa wyższego. Większy odsetek studentów w prywatnych kolegiach w porównaniu z prywatnymi uniwersytetami może wynikać z faktu, iż w 2000 roku państwowe i prywatne kolegia jednocześnie rozpoczęły działalność na edukacyjnym rynku litewskim.

${ }_{5}$ Uchwała Trybunału Konstytucyjnego w sprawie liczby studentów z dnia 5 lutego 2002 roku [Dokument elektroniczny, tryb dostępu: http://www.lrkt.lt/dokumentai/2002/n020205.htm, data wejścia; 25.05.2014]. 


\section{4. „Koszyk studenta” oraz dalsza liberalizacja rynku szkolnictwa wyższego}

Kolejne zmiany w szkolnictwie wyższym na Litwie nastapiły w 2009 roku, gdy wprowadzono „koszyk studenta” dyskutowany szeroko od 2005 roku. Model ten umożliwiał przyznanie budżetowych środków finansowych niepaństwowym szkołom wyższym, ponieważ studentowi, który otrzymał ,koszyk studenta”, gwarantował bezpłatne studia oraz prawo do wyboru uczelni, na której będzie studiował ${ }^{6}$. Oznaczało to pojawienie się możliwości przeniesienia finansowego „koszyka studenta” również do uczelni niepaństwowych. Ogólna liczba „koszyków studenta” została podzielona na dwie części: jedną część przeznaczono na realizację studiów na uniwersytetach, drugą zaś - w kolegiach. W ten sposób miała miejsce liberalizacja szkolnictwa wyższego na Litwie i niepaństwowe szkoły wyższe mogły korzystać z finansów budżetowych państwa. Z drugiej strony należy także odnotować, że państwo, wprowadzając model „koszyka studenta", uzyskało szansę korygowania strumienia przyszłych studentów, przyznając na kierunki ważne dla rozwoju gospodarki kraju większą liczbę „koszyków studenta”. Stwarzało to możliwość bezpłatnych studiów dla większej liczby osób.

TABELA 5.

„Koszyki studenta” przyznawane na studiach uniwersyteckich

\begin{tabular}{|c|c|c|c|c|c|c|c|}
\hline & Rok & 2009 & 2010 & 2011 & 2012 & 2013 & 2014 \\
\hline & Studia uniwersyteckie ogółem: & 11019 & 9680 & 9680 & 8975 & 7774 & 7576 \\
\hline- & nauki humanistyczne & 1326 & 1132 & 1137 & 1103 & 999 & 999 \\
\hline- & nauki społeczne & 3074 & 3094 & 3074 & 2692 & 2238 & 1955 \\
\hline- & nauki ścisłe & 1698 & 1325 & 1335 & 1295 & 1166 & 1166 \\
\hline- & nauki techniczne & 2946 & 2462 & 2467 & 2275 & 2065 & 2065 \\
\hline- & nauki biomedyczne & 1289 & 1123 & 1123 & 1089 & 925 & 1010 \\
\hline- & nauki artystyczne & 686 & 544 & 544 & 521 & 381 & 381 \\
\hline
\end{tabular}

Źródło: [Sejm Republiki Litewskiej, dokument elektroniczny, tryb dostępu: lrs.lt, data wejścia: 25.05.2014].

TABELA 6.

„Koszyki studenta” przyznawane na studiach w kolegiach

\begin{tabular}{|l|c|c|c|c|c|c|}
\hline Rok & $\mathbf{2 0 0 9}$ & $\mathbf{2 0 1 0}$ & $\mathbf{2 0 1 1}$ & $\mathbf{2 0 1 2}$ & $\mathbf{2 0 1 3}$ & $\mathbf{2 0 1 4}$ \\
\hline Studia w kolegiach ogółem: & 10151 & 9164 & 9165 & 8224 & 7038 & 6874 \\
$-\quad$ nauki humanistyczne & 222 & 70 & 70 & 67 & 58 & 58 \\
- nauki społeczne & 3724 & 3466 & 3312 & 2798 & 2237 & 1989 \\
- nauki ścisłe & 147 & 164 & 200 & 192 & 157 & 188 \\
- nauki techniczne & 4194 & 3661 & 3690 & 3308 & 2954 & 2987 \\
- nauki biomedyczne & 1356 & 1491 & 1655 & 1635 & 1473 & 1493 \\
- nauki artystyczne & 508 & 312 & 238 & 224 & 159 & 159 \\
\hline
\end{tabular}

Źródło: [Sejm Republiki Litewskiej, dokument elektroniczny, tryb dostępu: lrs.lt, data wejścia: 25.05.2014].

6 Więcej na ten temat zobacz: [Wołkonowski, 2009, s. 143-158]. 
Dane zawarte w tabelach: 5. i 6. świadczą o tym, że liczba bezpłatnych miejsc na studiach, tzn. liczba „koszyków studenta”, z każdym rokiem się zmniejszała. Przyczyną był niż demograficzny na Litwie i w związku z tym kurcząca się liczba maturzystów. Niemniej można zauważyć tendencję wzrostu udziału kierunków studiów: biomedycznych, fizycznych i technologicznych w kolegiach oraz utrzymanie dużego udziału tych kierunków na studiach uniwersyteckich.

22 grudnia 2011 roku Sąd Konstytucyjny Litwy uznał, że przyznanie „koszyka studenta" dla kandydatów ubiegających się na studia w niepaństwowych uczelniach jest niezgodne z 41. artykułem Konstytucji Litwy, który głosi, że państwo zapewni bezpłatne studia tylko zdolnym studentom na państwowych wyższych uczelniach ${ }^{7}$, stąd zobowiązał sejm i rząd Litwy do zmiany modelu finansowania szkolnictwa wyższego ${ }^{8}$. Na skutek tych decyzji, wiosną 2012 roku państwowe finansowanie szkolnictwa wyższego (za pomoca narzędzia ,koszyka studenta”) w znowelizowanej ustawie o studiach i nauce zostało ograniczone tylko do uczelni państwowych, zaś liberalny model finansowania szkolnictwa wyższego, traktujący na równi państwowe i niepaństwowe wyższe uczelnie, zostawiono tylko dla 10\% kwoty finansów przyznanych na szkolnictwo wyższe, zamieniając nazwę „koszyka studenta” na ,stypendium państwowe” dla tej puli9. Był to prawdopodobnie pewien kompromis związany z załagodzeniem sytuacji powstałej po decyzji Sądu Konstytucyjnego Litwy.

Wysokość „koszyka studenta” (lub „stypendium państwowego” dla 10\%) w zależności od kierunku studiów kształtuje się od 3892 Lt do 18162 Lt $^{10}$. Uczelnie, które zostały wybrane przez studentów dysponujących „koszykiem”, otrzymują te środki z budżetu państwa i prowadzą studia dzięki tym funduszom. Każdego roku podczas rekrutacji na studia odbywa się podział „koszyków studentów” na podstawie wyników egzaminów maturalnych kandydatów na studia, którzy również dokonują wyboru uczelni, rejestrując się w internetowym, ogólnokrajowym systemie rekrutacyjnym. Taki model, dający szeroki wybór studiów na wszystkich uczelniach w kraju, prowadzi także do rywalizacji między uczelniami o kandydatów na studia dysponujące „koszykiem studenta” (lub „stypendium państwowym” dla 10\%). Po wyczerpaniu limitu „koszyków studenta” (lub „stypendium państwowego” dla 10\%) szkoły wyższe, konkurując ze soba, przyjmują kandydatów na płatne miejsca.

Do realizacji powyższego modelu każdego roku w budżecie Litwy przyznaje się określoną kwotę na finansowanie szkolnictwa wyższego. Wysokość „koszyka studenta" jest sumą wszystkich wydatków niezbędnych do prowadzenia studiów dla jednego studenta i zależy od kierunku studiów. Uczelnia wyższa otrzymuje koszyk finanso-

7 Dokument elektroniczny, tryb dostępu: [http://www3.lrs.lt/pls/inter3/dokpaieska.showdoc _l?p_id=1890\&p_tr2=2, data wejścia: 25.05.2014].

${ }^{8}$ Punkt 37. wyroku Sądu Konstytucyjnego z dnia 22 grudnia 2011 roku [Dokument elektroniczny, tryb dostępu: http://www.lrkt.lt/dokumentai/2011/n111222.htm, data wejścia: 25.05.2014].

9 Artykuł 71. p. 2. znowelizowanej ustawy o nauce i studiach [Dokument elektroniczny, tryb dostępu: http://www3.lrs.lt/pls/inter3/dokpaieska.showdoc_l?p_id=474734, data wejścia: 25.05.2014].

10 Ministerstwo Nauki i Oświaty Republiki Litewskiej określa corocznie wysokość koszyka dla każdego kierunku studiów. Dla 2014 roku zostały przyjęte w dniu 29.11.2013 [Dokument elektroniczny, tryb dostępu: http://www3.lrs.lt/pls/inter3/dokpaieska.showdoc_l?p_id=461341\&p_tr2=2, data wejścia: 25.05.2014]. 
wy w toku realizacji studiów (środki te są przeznaczane na opłatę kosztów prowadzenia studiów).

RYSUNEK 1.

Finansowanie uczelni wyższych (w mln Lt) z budżetu państwa w latach 2003-2012

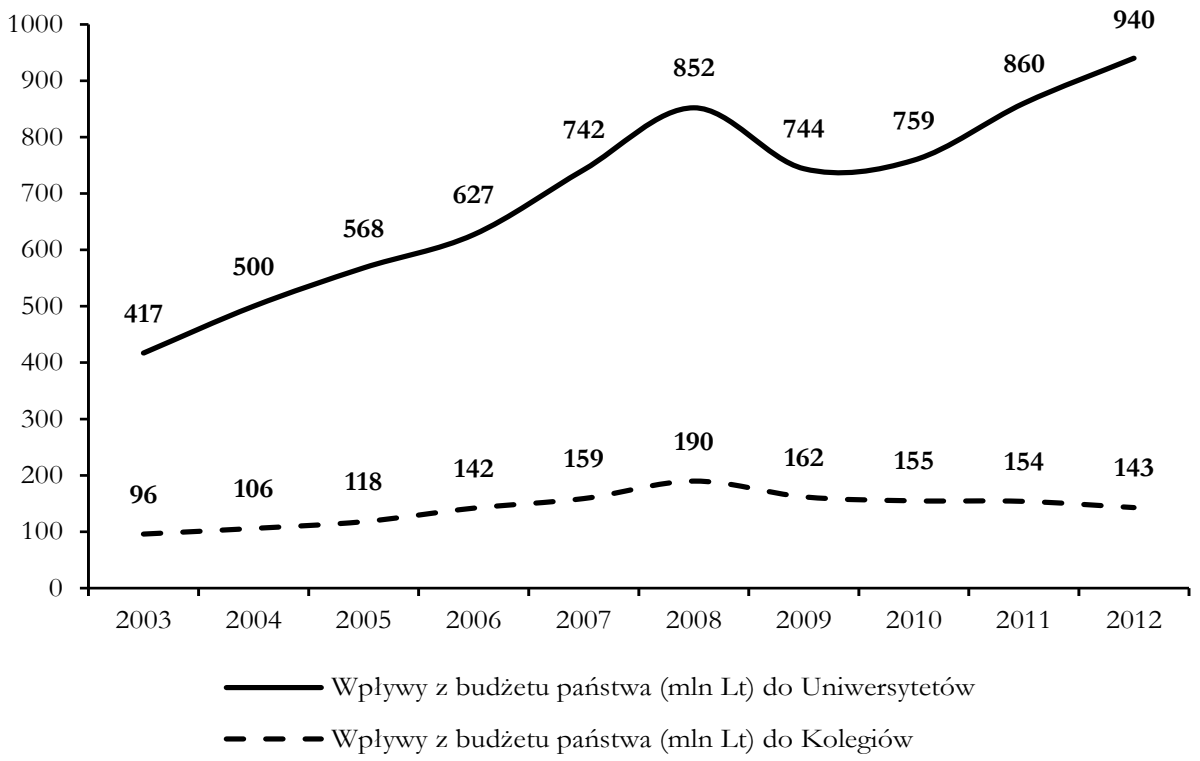

Źródło: [Departament Statystyki Litwy, dokument elektroniczny, tryb dostępu: stat.gov.lt, data wejścia: 25.05.2014].

W celu oceny stanu finansowania szkolnictwa wyższego na Litwie warto porównać go z wydatkami na szkolnictwo wyższe w krajach Unii Europejskiej i innych krajach świata oraz ze średnia unijna. Dobrym wskaźnikiem w tym przypadku jest porównanie poziomu finansowania szkolnictwa wyższego z PKB. Po uwzględnieniu tego miernika, poziom finansowania szkolnictwa wyższego na Litwie okazał się relatywnie wysoki w porównaniu z innymi krajami - tabela 7.

TABELA 7.

Wydatki na szkolnictwo wyższe w wybranych krajach UE i świata (w \% PKB)

\begin{tabular}{|c|c|c|c|c|c|c|c|c|c|c|c|}
\hline Rok & $\mathbf{2 0 0 1}$ & $\mathbf{2 0 0 2}$ & $\mathbf{2 0 0 3}$ & $\mathbf{2 0 0 4}$ & $\mathbf{2 0 0 5}$ & $\mathbf{2 0 0 6}$ & $\mathbf{2 0 0 7}$ & $\mathbf{2 0 0 8}$ & $\mathbf{2 0 0 9}$ & $\mathbf{2 0 1 0}$ & $\mathbf{2 0 1 1}$ \\
\hline EU 27 & 1,08 & 1,15 & 1,14 & 1,13 & 1,15 & 1,13 & 1,11 & 1,14 & 1,22 & 1,25 & 1,27 \\
Estonia & 1,03 & 1,08 & 1,02 & 0,86 & 0,92 & 0,90 & 1,04 & 1,12 & 1,33 & 1,23 & 1,29 \\
Lotwa & 0,9 & 0,85 & 0,74 & 0,68 & 0,89 & 0,91 & 0,93 & 1,00 & 0,79 & 0,80 & 1,01 \\
Litwa & 1,33 & 1,39 & 0,99 & 1,06 & 1,02 & 0,99 & 1,01 & 1,03 & 1,14 & 1,26 & 1,47 \\
Polska & 0,99 & 1,05 & 1,02 & 1,15 & 1,19 & 0,96 & 0,93 & 1,04 & 1,07 & 1,18 & 1,13 \\
USA & 1,46 & 1,34 & 1,43 & 1,25 & 1,27 & 1,38 & 1,22 & 1,23 & 1,20 & 1,36 & 1,34 \\
Japonia & 0,54 & 0,54 & 0,61 & 0,64 & 0,60 & 0,61 & 0,63 & 0,65 & 0,72 & 0,75 & 0,76 \\
\hline
\end{tabular}

Źródło: [Eurostat, dokument elektroniczny, tryb dostępu: http://appsso.eurostat.ec.europa.eu/ nui/submitViewTableAction.do, data wejścia: 25.05.2014]. 


\section{Podsumowanie}

W latach 1989-2014 w szkolnictwie wyższym na Litwie dokonano znacznych reform, podążając w kierunku liberalizacji szkolnictwa wyższego. Jedna z pierwszych radykalnych zmian polegała na stworzeniu dwufilarowego systemu szkolnictwa wyższego, składającego się ze studiów uniwersyteckich i nieuniwersyteckich studiów w kolegiach. Wprowadzenie płatnych studiów w celu zwiększenia ich dostępności było kolejnym krokiem w liberalizacji systemu szkolnictwa wyższego. Następnym posunięciem było wprowadzenie prywatnych uczelni (również zagranicznych, które otrzymały prawo zakładania na Litwie nowych uczelni oraz swych filii ${ }^{11}$ ) na rynek szkolnictwa wyższego w wyżej wymienionych filarach szkolnictwa wyższego. Najważniejszym działaniem w liberalizacji szkolnictwa wyższego było wdrożenie „koszyka studenta” zgodnie z zasadą ,pieniądze za studentem”. Stworzyło to jednakowe warunki funkcjonowania prywatnych i publicznych szkół wyższych oraz wniosło istotne elementy konkurencji w systemie szkolnictwa wyższego.

Obok tych pozytywnych zmian, warto także odnotować pewne niepowodzenia w reformowaniu szkolnictwa wyższego. Decyzją Sądu Konstytucyjnego Litwy w grudniu 2011 roku rynkowe rozwiązania finansowania szkolnictwa wyższego ograniczono tylko do uczelni państwowych. Liberalny model finansowania szkolnictwa wyższego zostawiono tylko dla 10\% kwoty finansów przyznanych na szkolnictwo wyższe. W zasadzie nie powiodła się optymalizacja szkół wyższych, która miała doprowadzić do powstania dużych uczelni dzięki fuzji istniejących uniwersytetów. Wprowadzenie ,koszyka studenta” oraz liberalizacja w pewnym stopniu osłabiły nieduże regionalne szkoły wyższe - uniwersytety i kolegia [Želvys, 2013, s. 17].

\section{Literatura}

Antonowicz D. 2005 Uniwersytet prayssłłości. Wyzwania i modele polityki, Instytut Spraw Publicznych, Warszawa.

Departament Statystyki Litwy, Kolegia na Litwie, dokument elektroniczny, tryb dostępu: [http://osp.stat.gov.lt/statistiniu-rodikliu-analize?id=1443\&status=A, data wejścia: 25.05 .2014$]$.

Departament Statystyki Litwy, Licz̧a prayjetych na studia do kolegiów, dokument elektroniczny, tryb dostępu: [http://osp.stat.gov.lt/statistiniu-rodikliu-analize?id=15 92\&status $=$ A, data wejścia: 25.05.2014].

Departament Statystyki Litwy, Liczba prayjetych na studia do uniwersytetów, dokument elektroniczny, tryb dostępu: [http://osp.stat.gov.lt/statistiniu-rodikliu-analize?id $=1593 \&$ status $=$ A, data wejścia: 25.05 .2014$]$.

Departament Statystyki Litwy, Licz̧ba studentów w kolegiach na Litwie, dokument elektroniczny, tryb dostępu: [http://osp.stat.gov.lt/statistiniu-rodikliu-analize?id=1444 \&status=A, data wejścia: 25.05.2014].

11 Więcej na ten temat: [Wołkonowski, 2008-2009a, s. 35-43; Wołkonowski, 2008-2009b, s. 197-203]. 


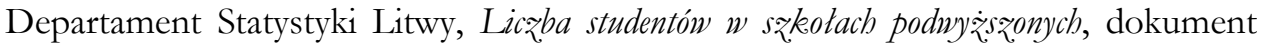
elektroniczny, tryb dostępu: [http://osp.stat.gov.lt/statistiniu-rodikliu-analize?id $=1668 \&$ status $=\mathrm{N}$, data wejścia: 25.05 .2014$]$.

Departament Statystyki Litwy, Liç̧a studentów w uniwersytetach na Litwie, dokument elektroniczny, tryb dostępu: [http://osp.stat.gov.lt/statistiniu-rodikliu-analize?id $=1714 \&$ status $=$ A, data wejścia: 25.05.2014].

Departament Statystyki Litwy, Licz̧ba sæzkót podwy ższonych, dokument elektroniczny, tryb dostępu: [http://osp.stat.gov.lt/statistiniu-rodikliu-analize?id=1228\&status=N, data wejścia: 25.05.2014].

Departament Statystyki Litwy, Licz̧ba uczelni, dokument elektroniczny, tryb dostępu: [http://osp.stat.gov.lt/statistiniu-rodikliu-analize?id=1494\&status $=A$, data wejścia: 25.05.2014].

Departament Statystyki Litwy, Liç̧ba uczniów i studentów, dokument elektroniczny, tryb dostępu: [http:// osp.stat.gov.lt/statistiniu-rodikliu-analize?id=1501\&status=A, data wejścia: 25.05.2014].

Departament Statystyki Litwy, Środki i dochody uczelni, dokument elektroniczny, tryb dostępu: [http://osp.stat.gov.lt/statistiniu-rodikliu-analize?id=1493\&status=A, data wejścia: 25.05.2014].

Eurostat, dokument elektroniczny, tryb dostępu: http://appsso.eurostat.ec.europa.eu/ nui/submitViewTableAction.do, data wejścia: 25.05.2014.

Eurostat, Expenditure on education as \% of GDP or public expenditure, dokument elektroniczny, tryb dostępu: [http://appsso.eurostat.ec.europa.eu/nui/submitView TableAction.do, data wejścia: 25.05.2014].

Konstytucja Republiki Litenskiej, (Lietuvos Respublikos Konstitucija), 1992, Valstybės žinios, 1992-11-30, nr 33-1014.

Marszałek A. 2010 Rola uczelni w regionie, Difin, Warszawa.

Ro:porzadzenie Ministra Oświaty i Nanki z dnia 12 lutego 2013 roku, nr V-107 - O preliminarnej licz̧bie finansowanych miejsc przezpanstwo na studiach pierwszego stopnia i jednolitych w 2013 roku (Dèl preliminaraus valstybès finansuojamu pirmosios pakopos ir vientisuju studiju vietu i kurias 2013 metais priimami studentai, skaičaus), Valstybès žinios, 201302-14, nr 17-839), dokument elektroniczny, tryb dostępu: [http://www3.lrs.lt/ pls/inter3/dokpaieska.showdoc_l?p_id=442988\&p_tr2=2, data wejścia: 25.05.2014].

Rozporzadzenie Ministra Oświaty i Nauki z dnia 13 lutego 2014 roku - O preliminarnej liczbie finansowanych miejsc przez panstwo na studiach pierwszego stopnia i jednolitych w 2014 roku (Del preliminaraus valstybeis finansuojamu pirmosios pakopos ir vientisuju studiju vietu. i kurias 2014 metais prïmami studentai, skaičians), Teisès aktų registras, 2014-02-14, nr 2014-01573, dokument elektroniczny, tryb dostępu: [http://www3.lrs.lt/pls/ inter3/dokpaieska.showdoc_l?p_id=465964\&p_tr2=2, data wejścia: 25.05.2014].

Rosporzadzenie Ministra Oswriaty $i$ Nauki z dnia 2 czerwca 2009 roku, nr ISAK-1163 - O preliminarnej liczbie finansowanych miejsc przez panstwo na studiach pierwszego stopnia i jednolitych w 2009 roku (Del preliminaraus valstybés finansuojamu pirmosios pakopos ir vientisuju studiju vietu i kurias 2009 metais priimami studentai, skaiciaus), Valstybès žinios, 200906-06, nr 67-2731, dokument elektroniczny, tryb dostępu: [http://www3.lrs.lt/ pls/inter3/dokpaieska.showdoc_l?p_id=345476\&p_tr2=2, data wejścia: 25.05.2014]. 
Rozporzqdzenie Ministra Oświaty i Nauki z dnia 23 lutego 2012 roku, nr V-324 - O preliminarnej liczbie finansowanych miejsc przez. państwo na studiach pierwszego stopnia i jednolitych w 2012 roku, (Dèl preliminaraus valstybes finansuojamu pirmosios pakopos ir vientisuju studiju vietu i kurias 2012 metais prïmami studentai, skaičiaus), Valstybès žinios, 201202-28, nr 25-1186, dokument elektroniczny, tryb dostępu: [http://www3.lrs.lt/ pls/inter3/dokpaieska.showdoc_l?p_id=418992\&p_tr2=2, data wejścia: 25.05.2014].

Rozporzqdzenie Ministra Ośmiaty i Nauki z dnia 29 listopada 2013 roku, nr V-1166 - O zatwierdzeniu normatywnych cen studiów na wyższych uczelniach dla studentów prayjetych w 2014 roku (Dèl studentu, prïmamu 2014 metais $\dot{i}$ aukśstasias moky)klas, norminiu studiju kainu patvirtinimo), Valstybės žinios, 2013-12-05, nr 124-6347, dokument elektroniczny, tryb dostępu: [http://www3.lrs.lt/pls/inter3/dokpaieska.showdoc_l?p_id=461341 \&p_tr2=2, data wejścia: 25.05.2014].

Rozporzadzenie Ministra Oświaty i Nauki z dnia 31 marca 2011 roku, nr V-541 - O preliminarnej liczbie finansowanych miejsc przez. panstwo na studiach pierwszego stopnia i jednolitych w 2011 roku (Dèl preliminaraus valstybes finansuojamu pirmosios pakopos ir vientisuju studiju vietu, i kurias 2011 metais priimami studentai, skaičiaus), (Valstybès žinios, 2011-04-09, nr 42-2017, dokument elektroniczny, tryb dostępu: [http://www3.lrs.lt/ pls/inter3/dokpaieska.showdoc_l?p_id=396218\&p_tr2=2, data wejścia: 25.05.2014]. Rozporzadzenie Ministra Oswiaty i Nauki z dnia 5 marca 2010 roku, nr V-302 - O preliminarnej liczbie finansowanych miejsc przez.panstwo na studiach pierwszego stopnia i jednolitych w 2010 roku (Dèl preliminaraus valstybes finansuojamu pirmosios pakopos ir vientisuju studiju vietu i kurias 2010 metais prïmami studentai, skaičiaus), Valstybès žinios, 201003-16, nr 30-1401, dokument elektroniczny, tryb dostępu: [http://www3.lrs.lt/ pls/inter3/dokpaieska.showdoc_l?p_id=366857\&p_tr2=2, data wejścia: 25.05.2014].

Sejm Republiki Litewskiej, dokument elektroniczny, tryb dostępu: [http://lrs.lt, data wejścia: 25.05.2014].

Statistical Yearbook of Lithuania 1989, 1990, Statistics Lithuania, Vilnius.

Statistical Yearbook of Lithuania 1994-1995, 1995, Statistics Lithuania, Vilnius.

Statistical Yearbook of Lithuania 1995-1996, 1996, Statistics Lithuania, Vilnius.

Statistical Yearbook of Lithuania 1996, 1996, Statistics Lithuania, Vilnius.

Thieme J. K. 2009 Szkolnictwo wyższe. Wyzwania XXI wieku Polska Europa USA, Difin, Warszawa.

Uchwała Sadu Konstytucyjnego z dnia 22 grudnia 2011 roku - O zodności ustawy o nauce $i$ studiach Republiki Litewskiej (redakecja z 30 kewietnia 2009 roku) z. Konstytucja Republiki Litewskiej (Del Lietuvos Respublikos mokslo ir studiu istatymo (2009 m. balandžio 30 d. redakcija) muostatu atitikties Lietuvos Respublikos Konstitucijai), Valstybès žinios, 2011-12-28, nr 160$-7591$.

Uchwała Sadu Konstytucyjnego z dnia 5 lutego 2002 roku - O zgodności ustawy słkolnictwa wyższego Republiki Litewskiej 8 artykutu 5 cześsi, 9 artykutu 3 czessci, 22 artykutu 3 cześci, 5 cześsci: 10, 11 i 12 punktów, 24 artykutu 1 czessci: 1, 2 i 5 punktów, 2 i 7 cressici, 42 artykutu 4 czessici, 60 artykutu, 61 artykutu 1 cześsci, 62 artykutu 1 cześsi i 65 artykutu 1 i 2 czessici z. Konstytucja Republiki Litewskiej (Del Lietuvos Respublikos aukštojo mokslo istatymo 8 straipsnio 5 dalies, 9 straipsnio 3 dalies, 22 straipsnio 3 dalies, 5 dalies: 10, 11 ir 12 punktu 24 straipsnio 1 dalies: 1, 2 ir 5 punk.tu 2 ir 7 daliu 42 straipsnio 4 dalies, 60 straipsnio, 61 straipsnio 1 dalies, 62 
straipsnio 1 dalies ir 65 straipsnio 1 ir 2 dalin atitikties Lietwvos Respublikos Konstitucijar), dokument elektroniczny, tryb dostępu: [http://www.lrkt.lt/dokumentai/2002/n0202 05.htm (publikacja tylko w wersji elektronicznej), data wejścia: 25.05.2014].

Ustawa o nauce $i$ studiach Republiki Litenskiej (Lietwos Respublokos mokslo ir studiju istatymas), Valstybès žinios, 2012-05-08, nr 53-2639, dokument elektroniczny, tryb dostępu: [http://www3.lrs.lt/pls/inter3/dokpaieska.showdoc_l?p_id=474734, data wejścia: 25.05.2014].

Wołkonowski J. 2008-2009a Reforma szkolnictwa wy ̇̇szego na Litwie, [w:] Rocznik Stowaryyszenia Naukowcón Polakón Litwy 2008-2009, T. 7-8, A. Grynia (red.), Stowarzyszenie Naukowców Polaków Litwy, Wilno.

Wołkonowski J. 2008-2009b Wileńska Filia Uniwersytetu w Bialymstoku a reforma školnictwa wyższego na Litwie, [w:] Rocznik. Stowaryyszenia Naukowcón Polaków Litwy 20082009, T 7-8., A. Grynia (red.), Stowarzyszenie Naukowców Polaków Litwy, Wilno.

Wołkonowski J. 2009 Aspekt polityczny reformy nanki i školnictwa wyższego na Litwre w latach 2007-2009, [w:] Zachód w globalnej i regionalnej polityce miedsynarodowej: teoria i praktyka, E. Kużelewska, A. Bartnicki (red.), Wydawnictwo Adam Marszałek, Toruń.

Želvys R. 2013 Švietimo politika: istorija ir dabartis, lietuvos aukšstojo mokslo studiju finansavimo politika: istorine raida ir ,studento krepsélio“" modelio idiegimo padariniai, „Acta Paedagogica Vilnensia", nr 31, Vilnius.

Zymonik Z. 2010 Uczelnia wyższa jako onganizacja trzeciej generacji, [w:] Wiedza w gospodarce i gospodarka oparta na wiedsy, M. Hopej, M. Moszkowicz, J. Skalik (red.), Wydawnictwo Uniwersytetu Ekonomicznego we Wrocławiu, Wrocław. 